\title{
Erratum to: Increased Expression of Beclin-1-Dependent Autophagy Protects Against Beta-amyloid-Induced Cell Injury in PC12 Cells
}

\author{
Zhongfeng Xue • Sheng Zhang • Liping Huang • \\ Yuping He • Ruoming Fang • Yongqi Fang
}

Published online: 8 May 2013

(C) Springer Science+Business Media New York 2013

\section{Erratum to: J Mol Neurosci}

$$
\text { DOI 10.1007/s12031-013-9974-y }
$$

The original version of this article ${ }^{1}$ unfortunately contained mistakes in the title and Figure 2 legend. The changes are underlined as follows:

\section{Article Title:}

Increased Expression of Beclin-1-Dependent Autophagy Protects Against Beta-amyloid-Induced Cell Injury in PC12 Cells

\section{Figure 2 legend:}

Fig. 2 A $\beta_{1-42}$-induced Beclin-1 expression was further upregulated by rapamycin but was downregulated by 3 -MA.
Cells were pretreated with or without 3-MA or rapamycin for $1 \mathrm{~h}$ before treatment with $1.25 \mu \mathrm{M}$ $\mathrm{A} \beta_{1-42}$ for 3-72 h. Beclin-1 expression was measured by flow cytometry. The untreated cells were used as control. The data of the experiments were expressed as mean $\pm \mathrm{SD} ; * P<0.05$ compared with $\underline{\mathrm{A} \beta \text {-treated group }}$

\section{References:}

1. Xue Z, Zhang S, Huang L, He Y, Fang R, Fang Y (2013) Upexpression of Beclin-1-Dependent Autophagy Protects Against Beta-amyloid-Induced Cell Injury in PC12 Cells. J Mol Neurosci. doi:10.1007/s12031-013-9974-y

The online version of the original article can be found at http://dx.doi.org/ 10.1007/s12031-013-9974-y.

Z. Xue $\cdot$ S. Zhang $\cdot$ L. Huang $\cdot$ Y. He $\cdot$ R. Fang $\cdot$ Y. Fang $(\bowtie)$

The First Affiliated Hospital of Guangzhou University of Chinese

Medicine, 16, Jichang Road,

Guangzhou 510405, China

e-mail: fangyq2@163.com 